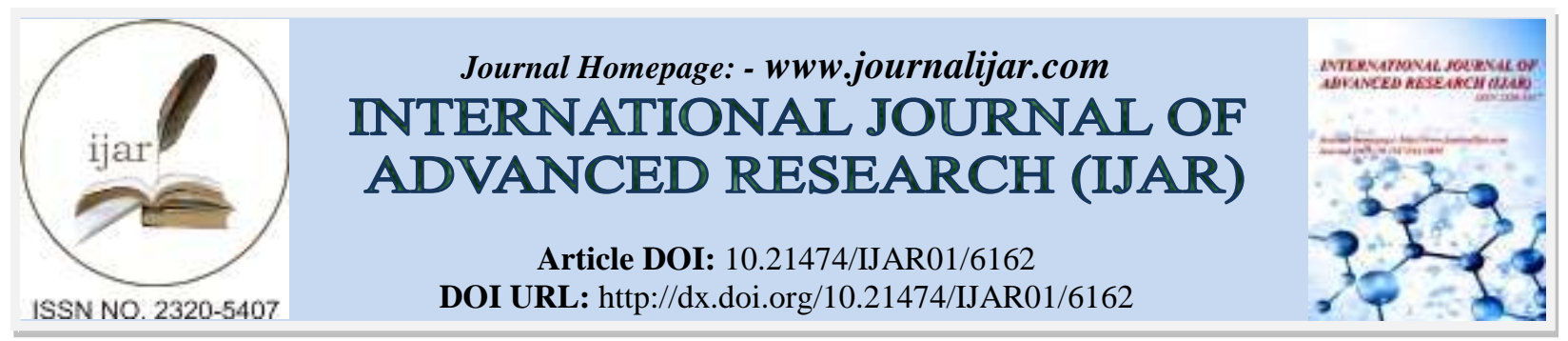

RESEARCH ARTICLE

\title{
IMPACT OF DEMONETIZATION ON SELECTED MICRO ENTERPRISES IN BENGALURU, KARNATAKA.
}

Mamatha $S^{1}$ and Subramanyam Mutyala ${ }^{2}$.

1. Research Scholar, School of Commerce and Management Studies, REVA University, Bangalore.

2. Research supervisor, School of Commerce and Management Studies, REVA University, Bangalore.

\section{Manuscript Info}

Manuscript History

Received: 25 October 2017

Final Accepted: 27 November 2017

Published: December 2017

Keywords:-

Demonetization, Micro Enterprises, Transaction.

\section{Abstract}

An enterprises important characteristic is to earn profit which plays a vital role in sustainability, for which earning returns is most important, but for an enterprise major part of their earning is through cash transactions. With the short history of objectives of an enterprise which helps us to analyse the importance of a transaction to a business to measure the financial position of the business. Cash is the most preferred mode of transaction by most of the Micro Enterprises only less than half of the population uses Banking system. The demonetization has initiated most of the Micro Enterprises to reduce cash transactions and prefer online transaction which has leading the economy towards cashless economy and also empowers banking services. Hence this study aims at enhancing cashless transactions which has its pros and cons in the initial stages. But this paper supports micro enterprises to develop a positive approach towards Demonetization and also tells about what are the post effects of demonetization on micro enterprises.

Copy Right, IJAR, 2017,. All rights reserved.

\section{Introduction:-}

Demonetization is the act of stripping a currency unit of its status as legal tender, it occurs whenever there is a change of national currency. The present form or forms of money is pulled from circulation and retired, often to be replaced with new notes or coins, sometimes a country completely replaces the old currency with new currency. It came as a surprise to everybody after our PM Narendra Modi declared on trashing the 500 and 1000 rupees notes. PM's move on banning the respective notes certainly may be the ray of hope to sweep out corruption and a boon to every tax-payer. The attempt to wipe out black money and corruption might be rigid, however was it really a wellplanned move? 
The various reasons why nations demonetize their local units of currency are, to change the currency of the nation, to revamp the value of the currency, to phase out older currency notes to replace with newer ones, to fight against inflation, to combat corruption and crime, to discourage a cash dependent economy and to ease trade.

India soon ground to a halt, businesses shut down, farmers reportedly couldn't buy seeds, taxi and rickshaw drivers didn't have any way to receive payments, employers had no way to pay their employees, hospitals were refusing patients who only had cash, fishermen watched their catch wither up and rot for lack of customers with usable money, weddings throughout the country were canceled, and some families reputedly even had difficulty buying food. It was a bona fide upheaval.

But India held it together. Through it all, besides some organized demonstrations by political opposition groups -who would probably protest anything the incumbent government does -- the way that India handled this extreme inconvenience could be described as dutiful: most people went out, stood in line, and did what they had to do without violence or, for the most part, chaos. Indians rich and poor, Hindu and Muslim, technologically-adept and off-the-grid were suddenly all tossed into the same boat and set adrift on the same sea. If nothing else, demonetization united India on a mutual mission: to comply with their government's policy and get life back to normal again as soon as possible.

The History of Demonetization in international and national level.

As it is discussed above the various reasons for demonetization the first three has a greater impact on foreign countries to go for demonetization.

1. A change in the currency of the nation an example for this will be adoption of euro as standard currency by all the institution of money, to facilitate this the authorities first fixed the exchange rate for each of the value euro into national standard after implementation of standard euro's the old currencies were demonetized.

2. Revamping the value of currency i.e. revaluation of standard currency due to various factors such as, Change in exchange rates and Hyperinflation.

An example of demonetization adopted for change in exchange rates is In 1980Zimbabwe dolor has an exchange rate of 1-1.25 of United States dolor as the time progress there was a decline in exchange rate this led to Abandonment of the currency in favor of other foreign currency.

3. Phasing out older currency notes to replace with newer ones. Reasons are:-

1. Counterfeit money

2. Upgrade the manufacturing materials into more secured or durable force

3. Replacement of lower value notes with coins.

4. In the year 1873 United States decided to demonetize silver coins in favor of adopting gold standard

\section{History of demonetization in India:-}

1. This is not the first time when Indian currency is demonetized in India.

2. First instance was in 1946 and the second in 1978 when a regulation was published to phase out notes with demonetization of Rs. 1000, Rs.5000 and Rs. 10000 these notes were never printed by RBI.

3. The reason for demonetization in 1946 and 1978 was to controlling unaccounted currency to curbing black money.

4. In 1978 the Janatha party coalition was led by Moraji Desai

5. He bought a second wave of demonetization by phasing out the same high value notes. It was not that successful as it was not support by then RBI Governor I G Patel.

6. Third such instance of demonetization was implemented in the year 2016

7. By Prime Minister Narendra Modi and the Reserve Bank of India have put a ban on currency notes of Rs.500 and Rs. 1000 on $8^{\text {th }}$ Nov. 2016 and announced of issue of new Rs.500 and Rs.2000 Bank notes in exchange for old Bank notes.

\section{Impacts of Demonetization on Indian Economy:-}

Demonetization is a generations' memorable experience and is going to be one of the economic events of our time.

Its impact is felt by every Indian citizen. Demonetization affects the economy through the liquidity side. Its effect will be a telling one because nearly $86 \%$ of currency value in circulation was withdrawn without replacing bulk of it. 
As a result of the withdrawal of Rs 500 and Rs 1000 notes, there occurred huge gap in the currency composition as after Rs 100; Rs 2000 is the only denomination.

Absence of intermediate denominations like Rs 500 and Rs 1000 will reduce the utility of Rs 2000. Effectively, this will make Rs 2000 less useful as a transaction currency though it can be a store value denomination.

Demonetization technically is a liquidity shock; a sudden stop in terms of currency availability. It creates a situation where lack of currencies jams consumption, investment, production, employment etc. In this context, the exercise may produce following short term/long term/, consumption/investment, welfare/growth impacts on Indian economy. The intensity of demonetization effects clearly depends upon the duration of the liquidity shocks. Following are the main impacts.

Demonetization is not a big disaster like global banking sector crisis of 2007; but at the same time, it will act as a liquidity shock that disturbs economic activities.

\section{Liquidity crunch (short term effect):-}

Liquidity shock means people are not able to get sufficient volume of popular denomination especially Rs 500. This currency unit is the favorable denomination in daily life. It constituted to nearly $49 \%$ of the previous currency supply in terms of value. Higher the time required to resupply Rs 500 notes, higher will be the duration of the liquidity crunch. Current reports indicate that all security printing presses can print only 2000 million units of RS 500 notes by the end of this year. Nearly 16000 MN Rs 500 notes were in circulation as on end March 2016. Some portion of this was filled by the new Rs 2000 notes. Towards end of March approximately $10000 \mathrm{MN}$ units will be printed and replaced. All these indicate that currency crunch will be in our economy for the next four months.

\section{Welfare loss for the currency using population:-}

Most active segments of the population who constitute the 'base of the pyramid' use currency to meet their transactions. The daily wage earners, other labourer, small traders etc. who reside out of the formal economy uses cash frequently. These sections will lose income in the absence of liquid cash. Cash stringency will compel firms to reduce labour cost and thus reduces income to the poor working class. There will be a trickle up effect of the liquidity chaos to the higher income people with time.

\section{Consumption will be hit:-}

When liquidity shortage strikes, it is consumption that is going to be adversely affected first.

\section{Consumption $\downarrow \rightarrow$ Production $\downarrow \rightarrow$ Employment $\downarrow \rightarrow$ Growth $\downarrow \rightarrow$ Tax revenue $\downarrow$}

\section{Loss of Growth momentum:-}

India risks its position of being the fastest growing largest economy: reduced consumption, income, investment etc. may reduce India's GDP growth as the liquidity impact itself may last three -four months.

\section{Impact on bank deposits and interest rate:-}

Deposit in the short term may rise, but in the long term, its effect will come down. The savings with the banks are actually liquid cash people stored. It is difficult to assume that such ready cash once stored in their hands will be put into savings for a long term. They saved this money into banks just to convert the old notes into new notes. These are not voluntary savings aimed to get interest. It will be converted into active liquidity by the savers when fullfledged new currency supply takes place. This means that new savings with banks is only transitory or short-term deposit. It may be encashed by the savers at the appropriate time. It is not necessary that demonetization will produce big savings in the banking system in the medium term. Most of the savings are obtained by biggie public sector banks like the SBI. They may reduce interest rate in the short/medium term. But they can't follow it in the long term.

\section{Impact on black money:-}

Only a small portion of black money is actually stored in the form of cash. Usually, black income is kept in the form of physical assets like gold, land, buildings etc. Hence the amount of black money countered by demonetization depends upon the amount of black money held in the form of cash and it will be smaller than expected. But more than anything else, demonetization has a big propaganda effect. People are now much convinced about the need to 
fight black income. Such a nationwide awareness and urge will encourage government to come out with even strong measures.

\section{Impact on counterfeit currency:-}

The real impact will be on counterfeit/fake currency as its circulation will be checked after this exercise. Demonetization as a cleaning exercise may produce several good things in the economy. At the same time, it creates unavoidable income and welfare losses to the poor sections of the society who gets income based on their daily work and those who doesn't have the digital transaction culture. Overall economic actives will be dampened in the short term. But the unmeasurable benefits of having more transparency and reduced volume of black money activities can be pointed as long term benefits. (Tojo Jose, 2017)

\section{Objectives:-}

1. To trace history of demonetization.

2. To examine the pre, post and during effect demonetization on Micro Enterprises.

3. To know the impact of Demonetization on customers behavior.

4. To know the impact of Demonetization on sustainability of Micro Enterprises.

\section{Methodology:-}

The present study is analytical in nature it is mainly based on primary data. The sample size is 100 Micro Enterprises i.e. 65 Manufacturing and 35 Services in a sub-urban town of Bangalore. The questionnaire survey was administrated on selected Micro Enterprises based on convenience sampling method. The survey was conducted on Manufacturing and Services micro enterprises in selected area.

\section{Data Analysis and Interpretations:- Manufacturing units:-}

Manufacturing has emerged as one of the high growth sectors in India. Prime Minister of India, Mr. Narendra Modi, had launched the 'Make in India' program to place India on the world map as a manufacturing hub and give global recognition to the Indian economy. India is expected to become the fifth largest manufacturing country in the world by the end of year 2020 .

\section{Market Size:-}

The Gross Value Added (GVA) at basic constant (2011-12) prices from the manufacturing sector in India grew 7.9 per cent year-on-year in 2016-17, as per the 2nd provisional estimate of annual national income published by the Government of India. Under the Make in India initiative, the Government of India aims to increase the share of the manufacturing sector to the gross domestic product (GDP) to 25 per cent by 2022, from 16 per cent, and to create 100 million new jobs by 2022. Business conditions in the Indian manufacturing sector continue to remain positive.

According to Ms. De Lima "As the survey showed only a mild decline in manufacturing production in the last month of the year, the average reading for the October-December quarter remained in growth terrain, thereby suggesting a positive contribution from the sector to overall GDP in Q3 FY17,"

Table 1:-Impact of Demonetization on Manufacturing Micro Enterprises -Before, During and After (In Percentage)

\begin{tabular}{|l|l|c|c|c|c|}
\hline $\begin{array}{c}\text { Sl. } \\
\text { No. }\end{array}$ & \multicolumn{1}{|c|}{ Type of unit } & $\begin{array}{c}\text { Before } \\
\text { Average) }\end{array}$ & $\begin{array}{c}\text { During } \\
\text { (Average) }\end{array}$ & $\begin{array}{c}\text { After } \\
\text { (Average) }\end{array}$ & No. units \\
\hline 1. & Carpentry & $10 \%$ & $12 \%$ & $15 \%$ & 04 \\
\hline 2. & Black smith & $06 \%$ & $06 \%$ & $06 \%$ & 06 \\
\hline 3. & pottery & $07 \%$ & $08 \%$ & $09 \%$ & 04 \\
\hline 4. & Goldsmith & $10 \%$ & $20 \%$ & $25 \%$ & 08 \\
\hline 5. & Agarabhathi & $10 \%$ & $12 \%$ & $13 \%$ & 04 \\
\hline 6. & Automobile component & $10 \%$ & $12 \%$ & $15 \%$ & 03 \\
\hline 7. & Electronic hardware & $10 \%$ & $11 \%$ & $12 \%$ & 08 \\
\hline 8. & Textile and garments & $10 \%$ & $08 \%$ & $09 \%$ & 10 \\
\hline 9. & Chemicals and Pharmaceutical & $20 \%$ & $20 \%$ & $20 \%$ & 10 \\
\hline 10. & Candle and pickle & $15 \%$ & $15 \%$ & $15 \%$ & 08 \\
\hline
\end{tabular}

Source: Primary Data 
The above table reveals about the rate of sales pre, during and post period of demonetization of manufacturing units expressed in percentages. If we observe unit wise, Carpentry (04 units) output before 10\%, during $12 \%$ and after demonetization 15\%, Blacksmith (06 units) output before $06 \%$, during also retained to $06 \%$ and after demonetization same again, Pottery (04 units) output before 07\%, during 08\% and after demonetization it raised to $9 \%$, Goldsmith (08 units) output before 10\%, during 20\% and after demonetization it raised to 25\%, Agarabhathi (04 units) output before 10\%, during 12\% and after demonetization 13\%, Automobile component (03 units) output before $10 \%$, during $12 \%$ and after demonetization it raised to $15 \%$, followed by Electronic hardware (08 units) output before $10 \%$, during $11 \%$ and after demonetization it raised to $12 \%$. Textile and garments 10 units output before $10 \%$, during $8 \%$, and after demonetization it raised to $9 \%$, Chemicals and pharmaceutical 10 units output before $10 \%$, during 10\%, and after demonetization $10 \%$ and Candle and pickle (10 units) output before $15 \%$, during $15 \%$ and after demonetization $15 \%$. It is found that, the impact of demonetization on Carpentry is favorable as it has effected in the growth of sales in this sector. On Blacksmith the impact of demonetization is moderate as it has not affected this sector. On Pottery, it had an affirmatory development in these units, on Goldsmith it was a plus point as it has increased the sales. On Agarabhathi it very certain point as it has increased the sales. On Automobile component it was a plus point as it has increased the sales, on Electronic hardware it has an advantage to this sector as it has increased the sales, on Textile and garments the impact of demonetization is perverse as it has not raised their output, on Chemicals and pharmaceutical and on Candle and pickle The impact of demonetization is moderate as it has not affected this sector.

\section{Services units:-}

Service sector is hit very heard by Demonetization decision in November 2016 worst Slump in nearly three year is noted. The Nikkei India Services Purchasing Managers' Index (PMI), which tracks services sector companies on a monthly basis, stood at 46.7 in November, down from 54.5 in October. The Index slipped into contraction territory for the first time since June 2015 and pointed to the sharpest reduction in output for almost three years.

On other hand if we talk about Banking Sector this is the only sector which was benefited by that decision in many aspects, this move will pull a large chunk of first time users to banks, who will have to use the system at least once to exchange their old notes for new ones. According to a study conducted by Moody's, people tend to continue using banking services once they have crossed the 'first-time user' mark. This development will increase bank deposits by 1 to 2 percent compared to what they were before the demonetization scheme.

Table 2:- Impact of Demonetization on Service Micro Enterprises -Before, During and After (In Percentage)

\begin{tabular}{|l|l|l|l|l|l|}
\hline Sl. No. & Type of unit & Before & During & After & No. units \\
\hline 1. & Tourism & $10 \%$ & $5 \%$ & $5 \%$ & 02 \\
\hline 2. & Transportation & $5 \%$ & $6 \%$ & $7 \%$ & 02 \\
\hline 3. & Hospital & $10 \%$ & $12 \%$ & $12 \%$ & 02 \\
\hline 4. & Tailors & $15 \%$ & $10 \%$ & $15 \%$ & 10 \\
\hline 5. & Real estate services & $05 \%$ & $16 \%$ & $12 \%$ & 02 \\
\hline 6. & parlors & $09 \%$ & $08 \%$ & $10 \%$ & 08 \\
\hline 7. & Small retailers & $15 \%$ & $17 \%$ & $18 \%$ & 04 \\
\hline 8. & Banking and insurance & $11 \%$ & $50 \%$ & $50 \%$ & 02 \\
\hline 9. & Finance & $10 \%$ & $5 \%$ & $5 \%$ & 02 \\
\hline 10. & Educational and skill development & $10 \%$ & $10 \%$ & $10 \%$ & 01 \\
\hline \multicolumn{2}{|c|}{ Total Units } \\
\hline
\end{tabular}

Source: Primary Data

The above table reveals about the rate of sales pre, during and post period of demonetization of Service units expressed in percentages. If we observe unit wise, Tourism, 2 units showing the service output before it was $10 \%$ ,during it was $05 \%$ and after demonetization it was $05 \%$, followed by transportation 2 units output before it was $05 \%$, during it was $06 \%$ and after demonetization it raised to $07 \%$., Hospital 2 units output before it was $10 \%$, during it was $12 \%$ and after demonetization it was 12\%, tailor 10 units output before it was $15 \%$, during it was $10 \%$ and after demonetization it raised to $15 \%$, Real estate services 2 units Investment output before, it was $05 \%$, during it was $16 \%$, and after demonetization it was $12 \%$, Parlors 8 units sales output before it was $9 \%$, during it was $8 \%$ and after demonetization it was $10 \%$, Small retailers 4 units the sales output before it was $15 \%$, during it was $17 \%$ and after demonetization it was 18\%, Banking and insurance 2 units demand of requirement of financial assistance 
and transfer of risk before it was $11 \%$, during it was $50 \%$ and after demonetization it was $50 \%$, Finance 2 units demand of requirement of financial assistance before it was $10 \%$, during it was $5 \%$ and after demonetization it was $5 \%$, Educational and skill development 01 unit sales of an enterprise before it was $10 \%$, during it was $10 \%$ and after demonetization it was $\mathbf{1 0 \%}$. It is found that, the impact of demonetization on tourism, has a perverse impact as it has decreased demand for the service, the impact of demonetization on transportation is positive as it has increased the service, the impact of demonetization on Hospital is positive as it has increased the service, the impact of demonetization on tailoring is moderate as it has not affected this sector, the impact of demonetization on Real estate services is positive as it has increased the investment attitude of the public, the impact of demonetization on Parlors is positive as it has increased the sales of the parlors, the impact of demonetization on retailers. Is positive as it has increased the sales of the retailers. The demand in before demonetization was normal but after demonetization it has a greater impact on the growth. The reason one for the growth is mode of transactions. The demand in before demonetization was normal but after demonetization it has gone down and could not increase till 2 months. The demand for education and skill development is neither increased nor decreased it's the same. The interpretation concludes that demonetization has no effect on education and skill development.

\section{Finding of the study:-}

1. $85 \%$ of Micro Enterprises says that from $9^{\text {th }}$ November 2016 to December 2016 there was $30 \%$ increase in demand of the goods due to accepting the old currency.

2. But later after $10^{\text {th }}$ December 2016 there was $20 \%$ decrease in sale due to non availability of cash this lead to enhance online transactions.

3. Most of the suppliers extended the credit span of time for settlement.

4. More than $70 \%$ of Micro Enterprises had to extended the credit facilities to customers this had increased the sales of an enterprise.

5. $50 \%$ and above proprietors of micro enterprises started online transaction to meet this requirement most of the customers who did not had bank A/c. opened the account to facilitate online transactions .

6. All this had a positive impact on the growth of an enterprise and also to reduce cash transaction this was one of the strategy which helped most of the micro enterprises for their sustainability in the economy.

7. Micro Enterprises started accepting E-cash like pay tm Debit cards, internet banking etc. all this had a positive impact on development in their sales by $65 \%$.

8. This has also helped the micro enterprises to access the modern technology.

\section{Conclusion:-}

According to the report of the study, even though initially the demonetization effects on micro Enterprises were not that effective but in the later it has the positive impact on Micro Enterprises. It has also instigated the Micro Enterprises consumers to adopt cash less means of transactions i.e. by promoting E- cash payments. This was their main strategy for sustainability during demonetization.

This has developed the economy by reducing the block money and initiated the economy to be cash less economy which leads to proper accountability of cash showing positive growth of the economy.

\section{References:-}

1. "Demonetization : Impact on cashless payment system". Manpreet Kaur (2017)

2. "Demonetization : Impact on the Economy", NIPFP working 2016; 182: 1-17.

3. "Demonetization of Indian Rupee against Us \$ : A Historical Perspective. Discovery". $2014 ; 23$ (78) : 108112.Sunitha.

4. "Impact of demonetization of rupees 500 and rupees 1000 notes on automotive industry", Singh. S (2016), Retrieved from www.financialexpress.com .

5. Effects of demonetization in India-SSRG Journals.

6. https://en.wikipedia.org/wiki/2016/_Indian_banknote_demonetisation.

7. https://scholar.google.co.in/

8. https://www.pressreader.com/ india/the times of india- new-delhi edition/20161228/2814921160979235 retrieved as on December 28. ISBN:978-93-86171-21-4.

9. Mohd Ms “ Demonetization of currency Notes: Significance and challenges". International Journal of Innovative Research and advanced studies. (2016) 3(12). ISSN: 2394-4404:60-64.

10. Rao DK, Mukherjee DS, Kumar DS, Sengupta DP, Tondon S, Nayudu SH. 
11. RBI Billetibn December 2016

12. The times of india, Bangalore Thursday, (December $8^{\text {th }} 2016$ ).

13. Tojo Jose,2017 http://www.indianeconomy.net/splclassroom/309/what-are-the-impacts-of-demonetisation-onindian-economy/, 1 sepetember, 2017.

14. www.investopedia.com. 